\title{
Nitrogen Fertilizer Rate and Cultivar Interaction Effects on Nitrogen Recovery, Utilization Efficiency, and Agronomic Performance of Spring Barley
}

\author{
Yadeta Anbessa and Patricia Juskiw \\ Alberta Agriculture and Rural Development, Field Crop Development Centre, Lacombe, AB, Canada T4L 1W8
}

Correspondence should be addressed to Yadeta Anbessa, yadeta.kabeta@gov.ab.ca

Received 4 January 2012; Accepted 26 February 2012

Academic Editors: A. D. Arencibia, P. Soengas, B. Trognitz, and W. P. Williams

Copyright (C) 2012 Y. Anbessa and P. Juskiw. This is an open access article distributed under the Creative Commons Attribution License, which permits unrestricted use, distribution, and reproduction in any medium, provided the original work is properly cited.

A study was carried out at Lacombe, Alberta, to develop baseline information on nitrogen recovery, utilization efficiency, and agronomic performance of spring barley. This information may enable us to understand where the inefficiencies of $\mathrm{N}$ nutrition may lay and determine strategies to improve nitrogen use efficiency (NUE). Three divergent cultivars, "Manley" (two-rowed, tall, late maturing), "Noble" (six-rowed, mid-height, intermediate maturing), and "Tukwa" (six-rowed, semidwarf, early maturing), were grown under low $\left(0 \mathrm{~kg} \mathrm{ha}^{-1}\right)$, moderate $\left(50 \mathrm{~kg} \mathrm{ha}^{-1}\right)$ and high $\left(100 \mathrm{~kg} \mathrm{ha}^{-1}\right)$ rates of applied $\mathrm{N}$ fertilization. Both $\mathrm{N}$ recovery

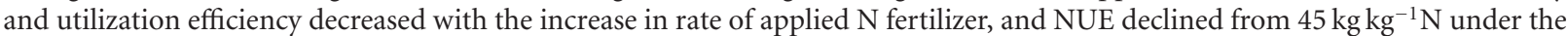
low $\mathrm{N}$ treatment to $33 \mathrm{~kg} \mathrm{~kg}^{-1} \mathrm{~N}$ under the moderate treatment and $24 \mathrm{~kg} \mathrm{~kg}^{-1} \mathrm{~N}$ under the high $\mathrm{N}$ treatment. The test cultivars were comparable in $\mathrm{N}$ uptake, but Tukwa and Noble were more efficient in their utilization of the $\mathrm{N}$ taken up than Manley, particularly under high N. Subsequently, while grain yield of Tukwa and Noble had increased linearly with rate of N fertilizer, the grain yield of Manley showed a declining trend under high $\mathrm{N}$. This implies that, where a high input condition is targeted, improvement in $\mathrm{N}$ utilization efficiency may need to be given due consideration.

\section{Introduction}

The cost of $\mathrm{N}$ fertilizers, as tied to the cost of natural gas and other contributing factors such as inflation, has sharply increased over the years. For example, in the last two decades alone, the average price for urea, one of the most commonly used forms of $\mathrm{N}$ fertilizer, has increased in the United States by about $150 \%$, from $\$ 212 \mathrm{Mg}^{-1}$ in the spring of 1991 to $\$ 526 \mathrm{Mg}^{-1}$ in the spring of 2011 [1]. This increase in cost of $\mathrm{N}$ fertilizers has certainly affected profit margins of primary producers particularly for low market value crops such as barley (Hordeum vulgare L.). In addition, there are increasing concerns about environmental pollution of excessive $\mathrm{N}$ from agricultural uses.

Improvement in nitrogen use efficiency (NUE) may increase net returns to producers and, at the same time, reduce the amount of $\mathrm{N}$ lost to the environment and its negative consequences. Nitrogen use efficiency is defined as grain yield per unit of $\mathrm{N}$ available to the crop, and it is the product of two primary components: the efficiency of recovery of available $\mathrm{N}$ from soil (often called $\mathrm{N}$ uptake efficiency, UpE) and the amount of grain yield produced per unit of $\mathrm{N}$ taken up by the crop (often called $\mathrm{N}$ utilization efficiency, UtE) [2]. Further, UtE is a function of the amount of dry matter produced per unit of $\mathrm{N}$ taken up (biomass production efficiency, BPE) and the partitioning efficiency of the dry matter produced to economic grain yield (harvest index, HI) [3].

Currently, recommendations for rate of applied $\mathrm{N}$ fertilizer in Alberta, Canada, as in many other locales, are the same across barley cultivars, although a slightly lower amount is recommended for malting cultivars to meet the moderate grain protein requirement by maltsters [4]. Nonetheless, studies have shown genetic differences in $\mathrm{N}$ recovery and utilization efficiencies of spring barley $[5,6]$. Barley cultivars are of different types that may 
affect their $\mathrm{N}$ uptake and utilization characteristics. Modern barley cultivars vary in height from semidwarf to the tall types. Considering spike characteristics, there are two-rowed and six-rowed types. The former generally produces more fertile tiller per plant, while the latter is superior in the number of kernels per ear. Nitrogen regime may affect these components differently. Information on the nature of fertilizer rate and cultivar interactions may be important to understand where the inefficiencies of $\mathrm{N}$ nutrition may lay and determine strategies to improve NUE associated with high-yielding characteristics. Therefore, the objectives of the present study were to (1) assess cultivar and fertilizer $\mathrm{N}$ rate interaction effects on grain yield and NUE of spring barley; (2) develop detailed characterization of fertilizer $\mathrm{N}$ recovery and utilization efficiency of spring barley cultivars under low, moderate, and high $\mathrm{N}$ regimes.

\section{Materials and Methods}

A field experiment was conducted at the Field Crop Development Centre's main research station near Lacombe, Alberta, Canada. This station is situated at $52^{\circ} 26^{\prime} \mathrm{N}$ latitude and $113^{\circ} 44^{\prime} \mathrm{W}$ longitude. Soil type at the station is a Penhold loam, Orthic Black Chernozem [7]. The seasonal precipitation and mean air temperatures recorded from an on-site LI-2000 Data Logger (LI-COR Biosciences, Lincoln, NE) are given in Table 1.

Treatments were comprised of three rates of applied $\mathrm{N}$ fertilizer and three barley cultivars. The $\mathrm{N}$ treatments were low $\left(0 \mathrm{kgha}^{-1}\right)$, moderate $\left(50 \mathrm{kgha}^{-1}\right)$, and high (100 kg ha $\left.{ }^{-1}\right)$. Urea (46-0-0) was used as the $\mathrm{N}$ source, and it was banded when seeding at a depth of $0.1 \mathrm{~m}$. The barley cultivars were Manley, Noble, and Tukwa. Manley is a tworowed, tall, late maturing, malting barley cultivar. Manley was developed by the University of Saskatchewan/Crop Development Centre from a cross of "Norbert"/MT54-7143 and supported for full registration in Canada in 1991 [8]. Manley was used as a parent for AC Metcalfe, the most commonly grown malting cultivar in western Canada. Noble and Tukwa are both six-rowed general purpose barleys. Noble has intermediate maturity and height [9], whereas Tukwa is an early maturing semidwarf [10]. The experiment was laid out in split-plot design with three replications, using $\mathrm{N}$ rates as main plot and cultivars as subplot treatments.

The experiment was seeded on May 31 in 1994, May 25 in 1995, and June 3 in 1996. Seeds were treated with $2 \mathrm{~mL} \mathrm{~kg}^{-1}$ of Vitavax single solution (i.e., carbathiin) (Bayer Crop Science, Calgary, Alberta, Canada) to protect against early season diseases. Plot size was eight rows of $8.5 \mathrm{~m}$ length and spacing of $0.2 \mathrm{~m}$ between rows. Seed rate was about 200 viable seeds $\mathrm{m}^{-2}$ with viability based on preplanting germination tests. Prior to seeding, soil samples were collected to a depth of $0.6 \mathrm{~m}$. Then, nitrate- $\mathrm{N}, \mathrm{P}, \mathrm{K}, \mathrm{S}, \mathrm{pH}$, electric conductivity, and soil organic matter were determined at the Soil and Crop Diagnostic Centre, Edmonton, Alberta, Canada (Table 1) [11]. At seeding in all three years, the plots were supplied with additional $31 \mathrm{~kg} \mathrm{~K} \mathrm{ha}^{-1}, 25 \mathrm{~kg} \mathrm{~S} \mathrm{ha}^{-1}$, and $7 \mathrm{kgPha}^{-1}$ banded at the depth of $0.12 \mathrm{~m}$. The $\mathrm{K}$ and $\mathrm{S}$ nutrients were supplied as potassium sulphate (0-0-52-17), while $\mathrm{P}$ was supplied as $\mathrm{P}_{2} \mathrm{O}_{5}(0-45-0)$. The plots were kept free of weeds with application of broadleaf herbicides recommended for barley [12] and/or hand weeding. Only hand weeding was used in 1994, while weeds were controlled in 1995 by application of REFINE (E.I. DuPont Canada Co., Mississauga, Ontario, Canada) at a rate of $0.02 \mathrm{~kg} \mathrm{ha}^{-1}$ and 2,4-D (BASF Canada, Mississauga, Ontario, Canada) at a rate of $1 \mathrm{~L} \mathrm{ha}^{-1}$ and, in 1996, by application of Buctril M (Bayer Crop Science, Calgary, Alberta, Canada) at a rate of $1 \mathrm{~L} \mathrm{ha}^{-1}$.

Plant samples were taken from one $0.5 \mathrm{~m}$ row each at heading and physiological maturity stages. The number of plants per sample row and tillers on each plant were counted. Leaf area was measured using a Monochrome Ag Vision System (Decagon Devices, Inc. Pullman, WA, US). The samples were separated into leaf, stem, and spike components. Dry weights and $\mathrm{N}$ contents were determined after drying in a forced air dryer. Tissue $\mathrm{N}$ contents were determined at the Soil and Crop Diagnostic Centre, Edmonton, Alberta, Canada [11]. Nitrogen uptake in the aboveground biomass was calculated as the sum of the product of leaf, stem, or spike dry weight and their respective $\mathrm{N}$ concentration. Percent increase in lodging incidence over the unfertilized treatment was assessed. Overall disease severity (scald and net blotch) was recorded on a 1-9 scale. Observation was also made on number of degree days from seeding to physiological maturity, that is, loss of green color from the peduncle of the main culm at approximately 35\% moisture content. Growing degree days (GDD) were computed using $0^{\circ} \mathrm{C}$ as base temperature as

$$
\mathrm{GDD}=\Sigma\left[\frac{\left(T_{\max }+T_{\min }\right)}{2}>0^{\circ} \mathrm{C}\right],
$$

where $T_{\max }$ is the maximum temperature and $T_{\min }$ is the minimum temperature.

After physiological maturity, the plots were harvested at approximately 15 to $25 \%$ moisture content on August 31 in 1994, September 22 in 1995, and September 3 in 1996. The central six rows of $2.74 \mathrm{~m}$ length were harvested using a binder (Suzue Manufacturing, Japan) to determine biomass and grain yield. The above ground part (straw + grain) was dried in a forced air dryer, and biomass was determined. These samples were threshed with a small-plot thresher, and grain yield was determined. Then, the following parameters were computed: (i) nitrogen use efficiency (NUE) — the ratio of grain yield to $\mathrm{N}$ supply, where $\mathrm{N}$ supply was defined as total $\mathrm{N}$ uptake in unfertilized plots at maturity plus $\mathrm{N}$ applied as fertilizer [13]; (ii) applied $\mathrm{N}$ use efficiency (ANUE) - the ratio of the increase in grain yield over the unfertilized treatment to the amount of $\mathrm{N}$ fertilizer applied; (iii) biomass production efficiency (BPE) - the ratio of the total biomass to the total aboveground $\mathrm{N}$ at maturity; (iv) nitrogen utilization efficiency (UtE) — the ratio of grain yield to the total aboveground $\mathrm{N}$ at maturity; (v) harvest index (HI) - the ratio of grain yield to the total aboveground biomass at harvest; (vi) grain $\mathrm{N}$ yield - the product of grain yield and grain $\mathrm{N}$ concentration.

Analysis of variance was carried out for each of the measured or computed parameters using PROC MIXED of SAS version 9.2 [14]. Fixed effects were $\mathrm{N}$ rates and cultivars. 
TABLE 1: Monthly rainfall ( $\mathrm{mm})$, mean air temperature, and soil characteristics of the Lacombe experimental site during 1994 to 1996.

\begin{tabular}{|c|c|c|c|}
\hline \multirow{2}{*}{ Variable } & \multicolumn{3}{|c|}{ Year } \\
\hline & 1994 & 1995 & 1996 \\
\hline \multicolumn{4}{|l|}{ Monthly rainfall (mm) } \\
\hline May & 21 & 42 & 54 \\
\hline June & 18 & 45 & 22 \\
\hline July & 55 & 81 & 34 \\
\hline August & 94 & 83 & 3 \\
\hline \multicolumn{4}{|c|}{ Monthly mean air temperature $\left({ }^{\circ} \mathrm{C}\right)$} \\
\hline May & 11.6 & 10.0 & 7.0 \\
\hline June & 14.8 & 14.8 & 13.3 \\
\hline July & 17.0 & 15.4 & 15.9 \\
\hline August & 15.6 & 12.3 & 15.9 \\
\hline \multicolumn{4}{|l|}{ Soil characteristics } \\
\hline Nitrate-N $\left(\mathrm{kg} \mathrm{ha}^{-1}\right)$ & 64 & 45 & 42 \\
\hline Phosphate $\left(\mathrm{kg} \mathrm{ha}^{-1}\right)$ & 72 & 38 & 13 \\
\hline Potassium $\left(\mathrm{kg} \mathrm{ha}^{-1}\right)$ & 510 & 225 & 227 \\
\hline Sulphate-S $\left(\mathrm{kg} \mathrm{ha}^{-1}\right)$ & 76 & 179 & 179 \\
\hline $\mathrm{pH}$ & 6.9 & 8.1 & 6.6 \\
\hline Electrical conductivity (dS/m) & 0.6 & 0.3 & 0.8 \\
\hline Organic matter $(\%)$ & 8.0 & 10.6 & 8.3 \\
\hline
\end{tabular}

Year, blocks within year, and their associated interactions were considered as random effects. Least-square means were obtained with the LSMEANS option of PROC MIXED and were separated at $P=0.05$ using the PDMIX800 macro of Saxton [15]. Contrast statements were used to test for linear and quadratic responses of the parameters measured to rate of $\mathrm{N}$ fertilizer. Finally, simple regression analysis was carried out using PROC REG of the SAS system to determine the relationship of grain yield and total $\mathrm{N}$ uptake at heading.

\section{Results}

3.1. Grain Yield and Yield Components. There were significant $(P<0.001)$ differences among $\mathrm{N}$ fertilizer rates in grain yield (Table 2). The cultivar and rate of $\mathrm{N}$ fertilizer interaction effect was also significant for grain yield, implying that the responses of different cultivars to rates of $\mathrm{N}$ fertilizer were different. Cultivars Tukwa and Noble had a linear grain yield response to increased rate of $\mathrm{N}$ fertilizer (Figure 1). On the other hand, neither linear nor quadratic grain yield responses to $\mathrm{N}$ rate were significant for Manley.

Application of $\mathrm{N}$ fertilizer did increase above-ground biomass for all the three cultivars (Table 3). Similar response to rate of $\mathrm{N}$ fertilizer was observed in total above-ground dry weight at heading (data not shown). The biomass-related trait of leaf area was also increased by the application of $\mathrm{N}$ fertilizer.

Comparing cultivars, Manley had relatively higher leaf area, number of tillers plant ${ }^{-1}$, and disease load and was later to mature (Table 3 ). These characteristics of leafiness and susceptibility to disease, growth cutoff before grain filling was completed for the late maturing cultivar Manley; may have contributed to its lack of grain yield response to increased rates of $\mathrm{N}$ fertilizer (Figure 1). Because of its tallness, Manley was also prone to lodging particularly under the high $\mathrm{N}$ rate. However, the lodging data was so variable, and it was not statistically different between treatments (Table 3 ).

3.2. Nitrogen Uptake. The $\mathrm{N}$ uptake in the aboveground biomass increased for all cultivars with the increase in rate of $\mathrm{N}$ fertilizer (Figure 2). Averaged over years and cultivars, biomass $\mathrm{N}$ uptake at maturity was $40 \%$ higher for the moderate and $67 \%$ higher for the high $\mathrm{N}$ rate over the unfertilized treatment. Nitrogen uptake at heading constituted over $75 \%$ of the $\mathrm{N}$ uptake at maturity across cultivars and rates of $\mathrm{N}$ fertilizer (Figure 2), indicating that the total $\mathrm{N}$ uptake was highly dependent upon preheading uptake under these growing and management conditions.

Like biomass $\mathrm{N}$, grain $\mathrm{N}$ yield increased with the rate of $\mathrm{N}$ fertilizer (Figure 2). Averaged over cultivars, grain $\mathrm{N}$ yield was 94, 126, and $146 \mathrm{~kg} \mathrm{ha}^{-1}$ for the low, moderate, and high $\mathrm{N}$ regimes, respectively. Grain $\mathrm{N}$ on average constituted about $75 \%$ of the biomass $\mathrm{N}$, with a range from 68 to $80 \%$ depending on specific cultivar $\times \mathrm{N}$ treatment. In general, the lower the rate of $\mathrm{N}$ fertilizer, the higher was the proportion of $\mathrm{N}$ partitioned to the grain. In this study, the average proportion of fertilizer $\mathrm{N}$ recovered in the grain was only $51 \%$ and $66 \%$ under the high and moderate $\mathrm{N}$ regimes, respectively. This proportion of $\mathrm{N}$ recovered in the grain would have been smaller, if computed for the total available $\mathrm{N}$ instead of fertilized $\mathrm{N}$.

3.3. Nitrogen Use Efficiency. As expected, NUE decreased with the increase in rate of $\mathrm{N}$ fertilizer applied (Table 4). There was an average decrease of $0.21 \mathrm{~kg} \mathrm{~kg}^{-1} \mathrm{~N}$ in NUE for each additional $\mathrm{kg}$ of $\mathrm{N}$ supplied to the plants. Applied 
TABle 2: $P$ values from the analysis of variance for the effects of $\mathrm{N}$ rate and cultivar on grain yield and nitrogen use efficiency traits in spring barley. Year, replications within year, and their associated interactions were considered random effects.

\begin{tabular}{|c|c|c|c|c|c|c|c|}
\hline Factor & $\begin{array}{c}\text { Grain yield } \\
\left(\mathrm{kg} \mathrm{ha}^{-1}\right)\end{array}$ & $\begin{array}{c}\text { NUE } \\
\left(\mathrm{kg} \mathrm{kg}^{-1} \mathrm{~N}\right)\end{array}$ & $\begin{array}{l}\text { Total N } \\
\text { uptake } \\
\left(\mathrm{kg} \mathrm{ha}^{-1}\right)\end{array}$ & $\begin{array}{c}\mathrm{UtE} \\
\left(\mathrm{kg} \mathrm{kg}^{-1} \mathrm{~N}\right)\end{array}$ & $\begin{array}{l}\mathrm{BPE}(\mathrm{kg} \\
\left.\mathrm{kg}^{-1} \mathrm{~N}\right)\end{array}$ & HI (\%) & $\begin{array}{l}\text { Grain N } \\
\text { yield } \\
\left(\mathrm{kg} \mathrm{ha}^{-1}\right)\end{array}$ \\
\hline $\mathrm{N}$ rate $(\mathrm{N})$ & $<0.001$ & $<0.001$ & $<0.001$ & 0.006 & 0.018 & 0.978 & $<0.001$ \\
\hline N-linear & $<0.001$ & $<0.001$ & $<0.001$ & 0.002 & 0.007 & 0.912 & $<0.001$ \\
\hline $\mathrm{N}$-quadratic & 0.036 & 0.202 & 0.238 & 0.591 & 0.759 & 0.870 & 0.151 \\
\hline Cultivar (C) & 0.566 & 0.795 & 0.402 & 0.002 & 0.189 & 0.004 & 0.829 \\
\hline $\mathrm{N} \times \mathrm{C}$ & 0.001 & 0.185 & 0.967 & 0.163 & 0.414 & $<0.001$ & 0.761 \\
\hline
\end{tabular}

NUE: nitrogen use efficiency, grain yield per unit of available $\mathrm{N}$ (soil $\mathrm{N}+$ applied); Total $\mathrm{N}$ uptake: the total $\mathrm{N}$ uptake in the biomass at maturity; UTE: nitrogen utilization efficiency, final grain yield per unit of $\mathrm{N}$ uptake; BPE: biomass production efficiency, biomass yield per unit of N taken up; HI: harvest index, the ratio of grain yield to biomass at harvest maturity; grain $\mathrm{N}$ yield was grain yield $\times$ grain $\mathrm{N}$ concentration.

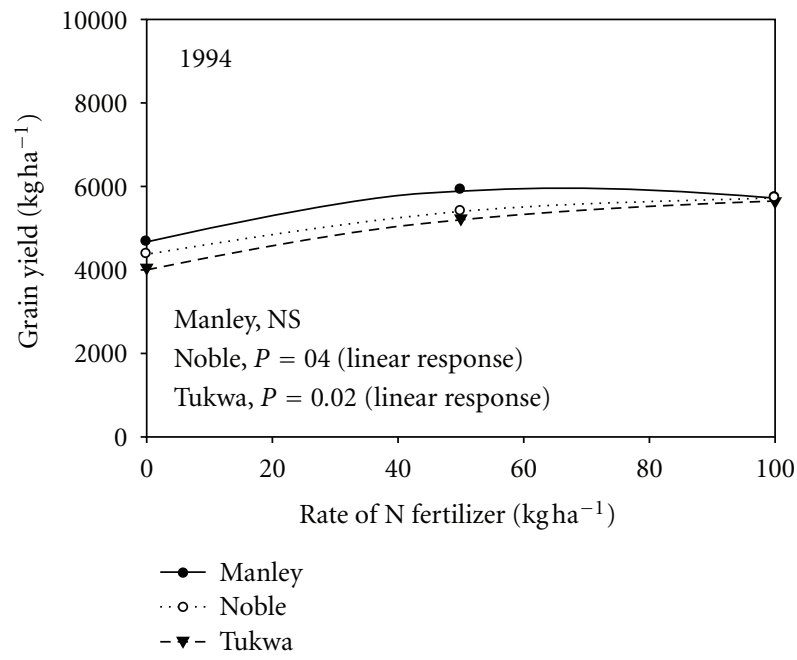

(a)

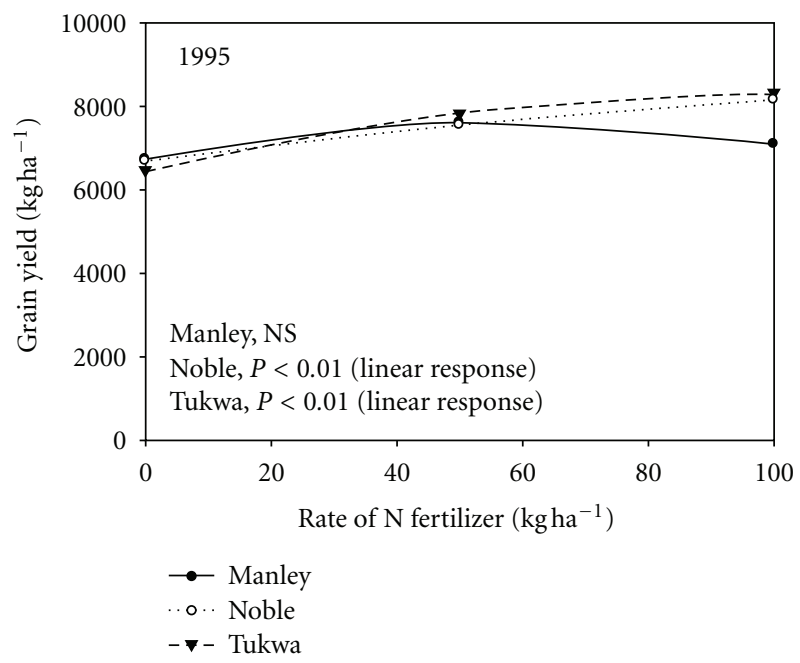

(c)

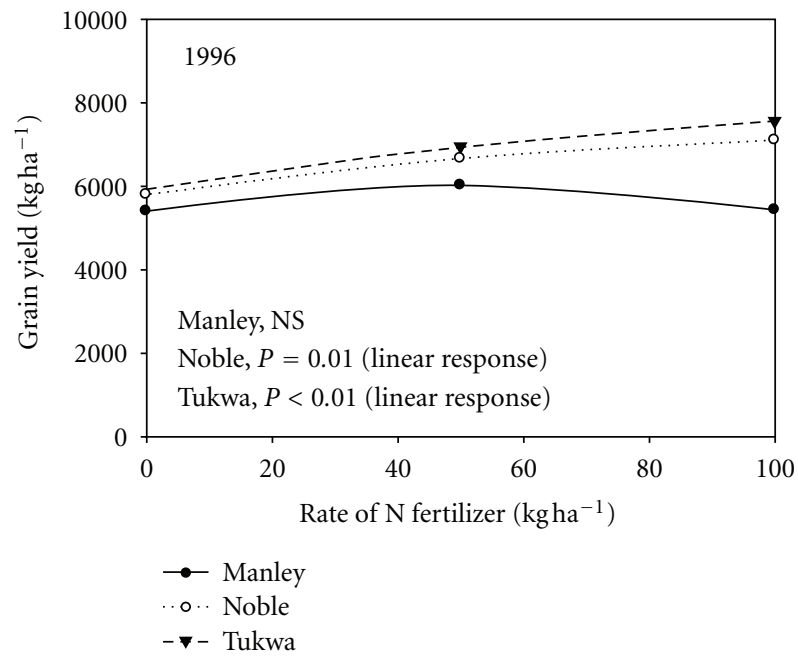

(b)

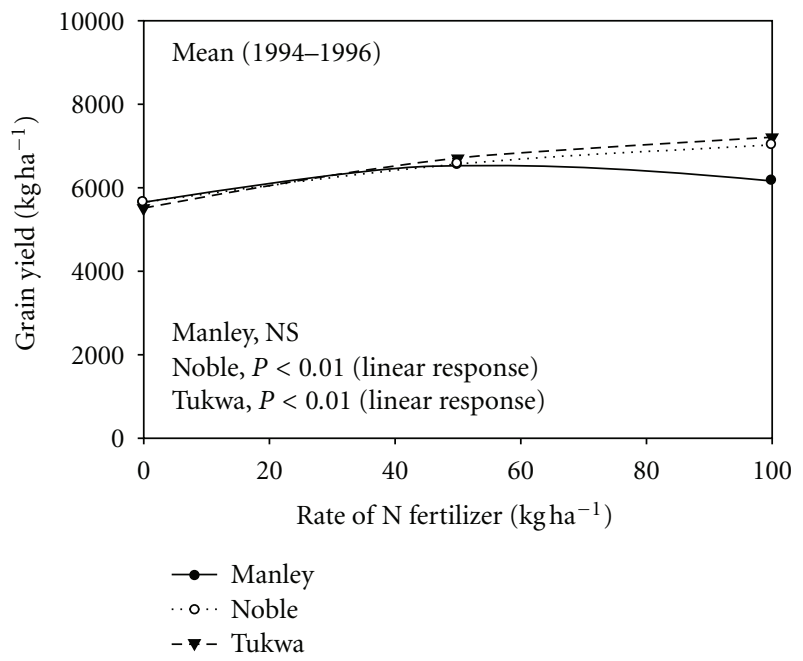

(d)

Figure 1: Grain yield of three spring barley cultivars grown under three rates of $\mathrm{N}$ fertilizer (0, 50, and $\left.100 \mathrm{~kg} \mathrm{ha}^{-1}\right)$ at Lacombe, Alberta, Canada, during 1994 to1996. $P$ values indicate significance of linear or quadratic responses to $\mathrm{N}$ rate as determined from orthogonal contrasts, NS indicates nonsignificant differences at $P=0.05$. 
TABle 3: Some agronomic characters of barley cultivars as influenced by rates of $\mathrm{N}$ fertilizer at Lacombe, Alberta, Canada, during 1994 to 1996.

\begin{tabular}{|c|c|c|c|c|c|c|c|}
\hline \multicolumn{2}{|c|}{ Variable } & \multirow{2}{*}{$\begin{array}{l}\text { Biomass } \\
\left(\mathrm{kg} \mathrm{ha}^{-1}\right)\end{array}$} & \multirow{2}{*}{$\begin{array}{l}\text { Leaf area } \\
\left(\mathrm{cm}^{2}\right)\end{array}$} & \multirow{2}{*}{$\begin{array}{l}\text { Number of } \\
\text { tillers plant }\end{array}$} & \multirow{2}{*}{$\begin{array}{l}\text { Time to maturity } \\
\text { (degree days) }\end{array}$} & \multirow{2}{*}{$\begin{array}{c}\text { Lodging } \\
\text { incidence } \\
(\%)\end{array}$} & \multirow{2}{*}{$\begin{array}{c}\text { Disease } \\
\text { score } \\
(1-9)\end{array}$} \\
\hline Cultivar & $N$ rate & & & & & & \\
\hline \multirow[t]{3}{*}{ Manley } & 0 & $10382 b$ & $173.3 \mathrm{~b}$ & $3.58 \mathrm{~b}$ & 1370.5 & 100 & 4.39 \\
\hline & 50 & $12135 a$ & $232.1 \mathrm{ab}$ & $3.82 \mathrm{~b}$ & 1387.3 & 141 & 4.39 \\
\hline & 100 & $12377 \mathrm{a}$ & $347.3 \mathrm{a}$ & $4.69 \mathrm{a}$ & 1398.0 & 152 & 4.67 \\
\hline \multirow[t]{3}{*}{ Noble } & 0 & $9588 b$ & $139.2 \mathrm{~b}$ & 3.40 & $1337.9 b$ & 100 & 2.94 \\
\hline & 50 & $11313 a$ & $219.5 \mathrm{a}$ & 3.73 & $1348.0 \mathrm{ab}$ & 102 & 3.39 \\
\hline & 100 & $12024 \mathrm{a}$ & $242.5 \mathrm{a}$ & 3.67 & $1374.2 \mathrm{a}$ & 147 & 3.06 \\
\hline \multirow[t]{3}{*}{ Tukwa } & 0 & $9683 b$ & $149.2 \mathrm{~b}$ & 3.40 & 1303.4 & 100 & 3.28 \\
\hline & 50 & $11299 a$ & $199.4 \mathrm{a}$ & 3.67 & 1312.2 & 137 & 3.28 \\
\hline & 100 & $11872 \mathrm{a}$ & $185.7 \mathrm{a}$ & 3.98 & 1323.1 & 131 & 3.06 \\
\hline \multirow[t]{3}{*}{ Mean } & 0 & $9884 b$ & $153.9 \mathrm{~b}$ & $3.46 \mathrm{~b}$ & 1337.3 & 100 & 3.54 \\
\hline & 50 & $11663 a$ & $217.0 \mathrm{ab}$ & $3.74 \mathrm{ab}$ & 1349.2 & 126 & 3.68 \\
\hline & 100 & $12010 \mathrm{a}$ & $258.5 \mathrm{a}$ & $4.11 \mathrm{a}$ & 1365.1 & 143 & 3.59 \\
\hline
\end{tabular}

Means of different $\mathrm{N}$ rates within cultivar or overall mean followed by different letters are significantly different at $P<0.05$. Lodging incidence was assessed as percent increase over the unfertilized plot.

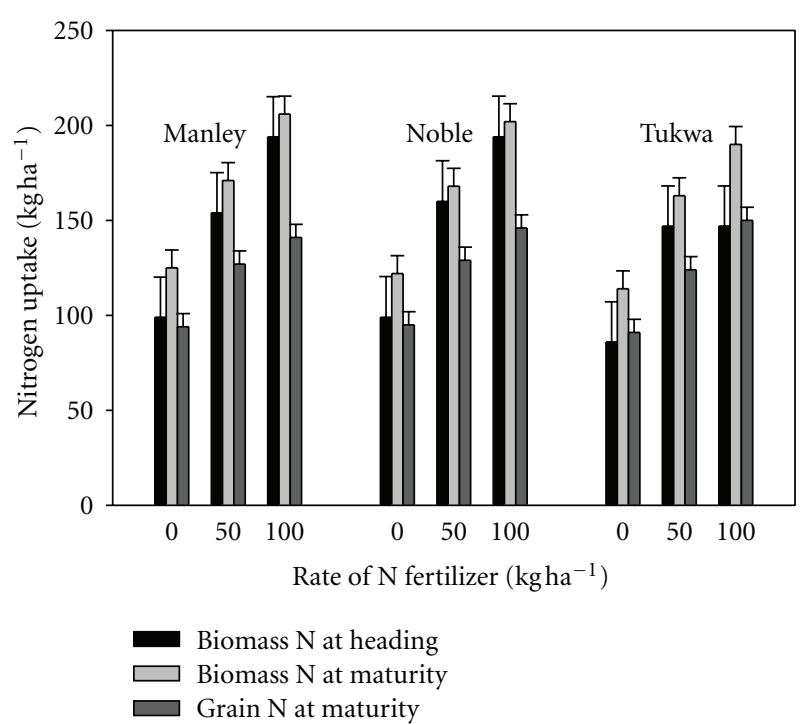

FIGURE 2: Nitrogen uptake in the above-ground biomass and grain in three spring barley cultivars grown under three rates of $\mathrm{N}$ fertilizer (0, 50, and $\left.100 \mathrm{~kg} \mathrm{ha}^{-1}\right)$ at Lacombe, Alberta, Canada, during 1994 to 1996. Bars indicate standard error of difference among $\mathrm{N}$ rates within each cultivar.

$\mathrm{N}$ use efficiency (ANUE) was 25 and $15 \mathrm{~kg} \mathrm{~kg}^{-1} \mathrm{~N}$ for the moderate and high $\mathrm{N}$ treatments, respectively (Table 4 ). For Manley, ANUE was very low at $6.6 \mathrm{~kg} \mathrm{~kg}^{-1} \mathrm{~N}$ under the high $\mathrm{N}$ treatment. The ANUE of Manley was comparable to that of Noble for the moderate $\mathrm{N}$ treatment, but its ANUE was only $38 \%$ of that of Noble and $31 \%$ of that of Tukwa under the high $\mathrm{N}$ regime.

Like NUE above, UtE decreased for all cultivars with the increase in the rate of $\mathrm{N}$ applied (Table 4). Differences were apparent among cultivars in UtE particularly under the high $\mathrm{N}$ rate. Under the high $\mathrm{N}$ rate, the UtE was $16 \%$ higher for Noble and 26\% higher for Tukwa as compared to Manley. Therefore, Noble and Tukwa were more efficient in utilization of the $\mathrm{N}$ taken up for grain formation than was Manley.

Nitrogen utilization efficiency was the product of BPE and HI. However, cultivar differences in UtE under the high $\mathrm{N}$ rate seem to have stemmed from differences in $\mathrm{HI}$ and not BPE. For the cultivar Manley with the lowest UtE, its HI with the high $\mathrm{N}$ treatment was $51 \%$ as compared to $59 \%$ for Noble and $61 \%$ for Tukwa.

\section{Discussion}

One of the objectives of this study was to develop baseline information on NUE characteristics of spring barley cultivars grown in the short-season, temperate environment of central Alberta, Canada. This baseline information could be used to streamline strategies and monitor progress in efforts aimed at improvement in NUE and grain yield. Our data showed that NUE was $45 \mathrm{~kg}$ grain $\mathrm{kg}^{-1} \mathrm{~N}$ under low $\mathrm{N}$ that was reduced to $33 \mathrm{~kg} \mathrm{~kg}^{-1} \mathrm{~N}$ under moderate $\mathrm{N}$ application and to $24 \mathrm{~kg} \mathrm{~kg}^{-1} \mathrm{~N}$ under high $\mathrm{N}$ application. Interestingly, these figures were comparable to the NUE estimates reported from the UK under 0 and $100 \mathrm{~kg} \mathrm{ha}^{-1}$ rates of $\mathrm{N}$ application [16]. In Finland, Muurinen et al. [17] also observed an average NUE of $24.2 \mathrm{~kg} \mathrm{~kg}^{-1} \mathrm{~N}$ for two-rowed and $23.3 \mathrm{~kg} \mathrm{~kg}^{-1} \mathrm{~N}$ for six-rowed barley grown under a high $\left(90 \mathrm{~kg} \mathrm{ha}^{-1}\right)$ rate of $\mathrm{N}$ application.

In this study, it was observed that, averaged over cultivars and years, only $52 \%$ of the applied $\mathrm{N}$ was recovered in the grain under high $\mathrm{N}$ application rate. Although this value was higher than the $33 \%$ estimated world average fertilizer $\mathrm{N}$ recovery in the grain of cereals [18], there is 
TABLE 4: Nitrogen use efficiency traits of three spring barley cultivars grown under three rates of $\mathrm{N}$ fertilizer $\left(0,50\right.$, and $100 \mathrm{~kg}$ ha $\left.{ }^{-1}\right)$ at Lacombe, Alberta, Canada, during 1994 to 1996.

\begin{tabular}{|c|c|c|c|c|c|c|c|}
\hline $\begin{array}{l}\text { Variable } \\
\text { Cultivar }\end{array}$ & $\mathrm{N}$ rate & $\begin{array}{c}\text { NUE } \\
\left(\mathrm{kg} \mathrm{kg}^{-1} \mathrm{~N}\right)\end{array}$ & $\begin{array}{l}\text { ANUE } \\
\left(\mathrm{kg} \mathrm{kg}^{-1} \mathrm{~N}\right)\end{array}$ & $\begin{array}{c}\mathrm{UtE} \\
\left(\mathrm{kg} \mathrm{kg}^{-1} \mathrm{~N}\right)\end{array}$ & $\begin{array}{l}\mathrm{BPE} \\
\left(\mathrm{kg} \mathrm{kg}^{-1} \mathrm{~N}\right)\end{array}$ & $\begin{array}{l}\mathrm{HI} \\
(\%)\end{array}$ & $\begin{array}{c}\text { Grain N } \\
\text { content } \\
(\%)\end{array}$ \\
\hline \multirow[t]{3}{*}{ Manley } & 0 & $46.7 \mathrm{a}$ & - & $45.1 \mathrm{a}$ & $85.2 \mathrm{a}$ & $54.3 \mathrm{a}$ & $1.69 \mathrm{c}$ \\
\hline & 50 & $32.5 b$ & 22.8 & $38.7 \mathrm{a}$ & $75.9 \mathrm{ab}$ & $53.2 \mathrm{ab}$ & $1.95 \mathrm{~b}$ \\
\hline & 100 & $21.8 \mathrm{c}$ & 6.6 & $30.1 \mathrm{~b}$ & $60.7 \mathrm{~b}$ & $50.8 \mathrm{~b}$ & $2.31 \mathrm{a}$ \\
\hline \multirow[t]{3}{*}{ Noble } & 0 & $46.9 a$ & - & $46.9 a$ & $81.5 \mathrm{a}$ & 58.6 & $1.71 \mathrm{c}$ \\
\hline & 50 & $32.6 \mathrm{~b}$ & 23.0 & $39.0 \mathrm{a}$ & $68.6 \mathrm{a}$ & 58.1 & $1.99 \mathrm{~b}$ \\
\hline & 100 & $25.5 c$ & 17.2 & $34.9 \mathrm{~b}$ & $61.5 \mathrm{~b}$ & 58.5 & $2.15 \mathrm{a}$ \\
\hline \multirow[t]{3}{*}{ Tukwa } & 0 & $45.8 \mathrm{a}$ & - & $47.9 \mathrm{a}$ & $85.5 a$ & $56.8 \mathrm{~b}$ & $1.67 \mathrm{c}$ \\
\hline & 50 & $33.2 \mathrm{~b}$ & 29.7 & $41.1 \mathrm{ab}$ & 71.1ab & $59.3 \mathrm{ab}$ & $1.86 \mathrm{~b}$ \\
\hline & 100 & $25.5 \mathrm{c}$ & 21.2 & $38.0 \mathrm{~b}$ & $64.1 \mathrm{~b}$ & $60.9 \mathrm{a}$ & $2.03 \mathrm{a}$ \\
\hline \multirow[t]{3}{*}{ Mean } & 0 & $46.5 \mathrm{a}$ & - & $46.6 \mathrm{a}$ & $84.1 \mathrm{a}$ & 56.6 & $1.69 c$ \\
\hline & 50 & $32.8 \mathrm{~b}$ & 25.2 & $39.6 b$ & $71.9 \mathrm{~b}$ & 56.7 & $1.93 \mathrm{~b}$ \\
\hline & 100 & $24.1 \mathrm{c}$ & 15.0 & $34.3 \mathrm{c}$ & $62.1 \mathrm{c}$ & 56.9 & $2.16 \mathrm{a}$ \\
\hline
\end{tabular}

NUE, nitrogen use efficiency, grain yield per unit of available $\mathrm{N}$ (soil $\mathrm{N}+$ applied); ANUE, applied nitrogen use efficiency, increase in grain yield over unfertilized control per unit of applied N; UTE, nitrogen utilization efficiency, final grain yield per unit of N uptake; BPE, biomass production efficiency, biomass yield per unit of $\mathrm{N}$ taken up; and $\mathrm{HI}$, harvest index, the ratio of grain yield to biomass at harvest maturity.

Means of different $\mathrm{N}$ rates within cultivar or overall mean followed by different letters are significantly different at $P<0.05$.

clearly a substantial shortfall in the proportion of $\mathrm{N}$ fertilizer that is taken up by the barley plant. It implies that, if a substantial progress is to be made in NUE, improvement in the efficiency of fertilizer $\mathrm{N}$ recovery is required particularly when developing cultivars through plant breeding. Increase in the efficiency of fertilizer $\mathrm{N}$ recovery may allow a reduction in rate of $\mathrm{N}$ fertilization while maintaining grain yield and is probably an important strategy to balance the desire to optimize current production on the one hand and environmental health and production sustainability on the other hand.

Previous studies in Alberta, Canada, in most part showed no interaction between spring barley cultivar and rate of $\mathrm{N}$ fertilizer for grain yield $[19,20]$. In contrast, the present study revealed differential grain yield response of cultivars to rates of $\mathrm{N}$ fertilizer. While two of the test cultivars Tukwa and Noble had an increase in grain yield due to the high $\left(100 \mathrm{~kg} \mathrm{~N} \mathrm{ha}^{-1}\right)$ rate, Manley attained its maximum yield at the moderate $\left(50 \mathrm{~kg} \mathrm{Nha}^{-1}\right)$ rate. In western Canada, Grant et al. [21] also observed that, under high moisture conditions the cultivar Bonanza attained its maximum grain yield at lower $\mathrm{N}$ levels than did other cultivars. This suggests that the rate of $\mathrm{N}$ fertilizer may be adjusted according to the cultivar to improve NUE while maintaining potential grain yield. In barley, where very diverse cultivar types are being developed and used (two-rowed versus six-rowed, tall versus semidwarf, malting versus general purpose), cultivarspecific recommendations for $\mathrm{N}$ fertilizer rate as a strategy to enhance NUE may be justified. With high fertilizer prices, even small differences in optimum $\mathrm{N}$ rate matter.

Since we found in this study that total $\mathrm{N}$ uptake in the above-ground biomass was similar across cultivars, the observed differences in grain yield response to high $\mathrm{N}$ regime and NUE were attributed to differences in the efficiency of utilization of the $\mathrm{N}$ taken up (i.e., UtE). Under high $\mathrm{N}$ conditions, a 30\% difference was observed in UtE between the most efficient cultivar Tukwa and the least efficient cultivar Manley. Similarly, Sinebo et al. [5] reported substantial cultivar differences in UtE that ranged from 32 to $48 \mathrm{~kg} \mathrm{~kg}^{-1} \mathrm{~N}$ for a high $\left(115 \mathrm{~kg} \mathrm{~N} \mathrm{ha}^{-1}\right)$ fertilizer treatment. Muurinen et al. [17] also observed with the application of $90 \mathrm{~kg} \mathrm{Nha}^{-1}$ under Nordic conditions, UtEs of 41 to $48 \mathrm{~kg} \mathrm{~kg}^{-1} \mathrm{~N}$ for two-rowed, and 42 to $53 \mathrm{~kg} \mathrm{~kg}^{-1} \mathrm{~N}$ for sixrowed barley cultivars. Where a high input condition is targeted, improvement in UtE may need to be emphasized to bring about desired changes in overall NUE.

Nitrogen utilization efficiency is a function of BPE and HI [3]. The three cultivars used in our study were similar in BPE across fertility regimes. However, under the high $\mathrm{N}$ conditions, HI was $61 \%$ for Tukwa and $59 \%$ for Noble as compared to $51 \%$ for Manley. Therefore, Tukwa's and Noble's higher utilization efficiency of the $\mathrm{N}$ taken up was attributed to their superior dry matter partitioning to the grain rather than total dry matter production. It is important to consider $\mathrm{HI}$ and UtE when developing cultivars for high $\mathrm{N}$ conditions and when making fertilizer $\mathrm{N}$ recommendations.

A high UtE is producing relatively more $\mathrm{C}$ per unit of $\mathrm{N}$ taken up and results in a low straw or grain $\mathrm{N}$ concentration. Our data ascertained that grain $\mathrm{N}$ content ranking of the test cultivars was in exact reverse order to their UtE under high $\mathrm{N}$ conditions. Therefore, breeding efforts to improve UtE and thereby NUE may have consequence on grain protein content. In malting barley, where low-to-moderate grain protein content is desired, the indirect effect of an increase in UtE of reducing grain protein would perhaps be positive. Even in barley that is used as an energy source for animals, a small reduction in protein content should be acceptable to the feed industry. Nonetheless, an increase in UtE under high 
$\mathrm{N}$ conditions would likely result from an increase in $\mathrm{HI}$ as demonstrated in this study, and because an increase in HI means an increase in dry matter and $\mathrm{N}$ partitioning to the grain, the compromise in grain protein due to an increase in UtE would only be slight.

In summary, the purpose of this study was simply to develop baseline information on nitrogen use efficiency characteristics of spring barley under low, moderate, and high rate of $\mathrm{N}$ regimes using data available in our data bank. It was observed that barley cultivars produce about $45 \mathrm{~kg}$ grain per $\mathrm{kg}$ of $\mathrm{N}$ supplied under low $\mathrm{N}$ conditions, that was reduced to $33 \mathrm{~kg} \mathrm{~kg}^{-1} \mathrm{~N}$ under moderate $\mathrm{N}$ application and to $24 \mathrm{~kg} \mathrm{~kg}^{-1} \mathrm{~N}$ under high $\mathrm{N}$ application. This means that there was an average decrease of $0.21 \mathrm{~kg} \mathrm{~kg}^{-1} \mathrm{~N}$ in NUE for each additional $\mathrm{kg}$ of $\mathrm{N}$ supplied to the plants. This information should be useful to measure current and future improvements in NUE and grain yield as well as streamline strategies for further improvements. The second important observation was that the test cultivars had differential responses to rate of $\mathrm{N}$ fertilization. While grain yields of Tukwa and Noble had a linear response to rate of $\mathrm{N}$ fertilizer, the grain yield of Manley showed a declining trend under high N. Manley was particularly low in UtE under high N conditions. It is, therefore, important to consider UtE when developing cultivars for high $\mathrm{N}$ conditions and when making fertilizer $\mathrm{N}$ recommendations.

\section{Abbreviations}

BPE: Biomass production efficiency

HI: $\quad$ Harvest index

NUE: Nitrogen use efficiency

UpE: Nitrogen uptake efficiency

UtE: Nitrogen utilization efficiency

ANUE: Applied nitrogen use efficiency.

\section{Acknowledgments}

The funding of this project by the Alberta Barley Commission, the Alberta Agriculture Research Institute, and Alberta Agriculture and Rural Development is gratefully acknowledged, as is the funding for current studies of Nitrogen Use Efficiency by the Alberta Crop Industry Development Fund. The technical assistance of Donna Westling and Tom Zatorski, then at FCDC, and Jill DeMulder, then at the Agronomy Unit, in trial management and data collection was greatly appreciated. The development of this project by Len Kryzanowski, Alberta Agriculture and Rural Development, and Dr. Yih-Wu Jame, then at Agriculture and Agri-Food Canada, is gratefully acknowledged.

\section{References}

[1] United States Department of Agriculture (USDA), "U.S. Fertilizer Use and Price," Economic Research Service, USDA, Washington, DC, USA, 2011, http://www.ers.usda.gov/Data/ FertilizerUse/.

[2] R. H. Moll, E. J. Kamprath, and W. Jackson, "Analysis and interpretation of factors which contribute to efficiency of nitrogen utilization," Agronomy Journal, vol. 74, no. 3, pp. 562-564, 1982.

[3] J. I. Ortiz-Monasterio, K. D. Sayre, S. Rajaram, and M. McMahon, "Genetic progress in wheat yield and nitrogen use efficiency under four nitrogen rates," Crop Science, vol. 37, no. 3, pp. 898-904, 1997.

[4] Alberta Agriculture, Food and Rural Development, Agronomic and Fertilizer Management of Barley in Alberta, 2008, http://www1.agric.gov.ab.ca/\$department/deptdocs.nsf/all/ agdex12433/.

[5] W. Sinebo, R. Gretzmacher, and A. Edelbauer, "Genotypic variation for nitrogen use efficiency in Ethiopian barley," Field Crops Research, vol. 85, no. 1, pp. 43-60, 2004.

[6] Y. Anbessa, P. Juskiw, A. Good, J. Nyachiro, and J. Helm, "Genetic variability in nitrogen use efficiency of spring barley," Crop Science, vol. 49, no. 4, pp. 1259-1269, 2009.

[7] “The Alberta Soil Information Viewer," Alberta Agriculture and Rural Development, 2011, http://www1.agric.gov.ab.ca/ \$department/deptdocs.nsf/all/sag10372/.

[8] Canadian Food Inspection Agency (CFIA), "Barley List of Varieties which are Registered in Canada," CFIA, Ottawa, Canada, 2008, http://www.inspection.gc.ca/english/plaveg/variet/barorge.shtml.

[9] J. Helm, D. Salmon, D. Dyson, and W. Stewart, "Registration of "Noble" barley," Crop Science, vol. 29, no. 1, p. 235, 1989.

[10] J. Helm, M. Cortez, D. Salmon, P. Jedel, and W. Stewart, "Registration of "Tukwa" barley," Crop Science, vol. 36, no. 3, p. 809, 1996.

[11] Alberta Agriculture, Standard Operating Procedures Manual, Soil and Crop Diagnostic Centre, Edmonton, Alberta, Canada, 1995.

[12] Alberta Agriculture and Food, Crop Protection Guide, Alberta Agriculture, Food and Rural Development, Information Package Centre, Edmonton, Alberta, Canada, 2000.

[13] A. Limon-Ortega, K. D. Sayre, and C. A. Francis, "Wheat nitrogen use efficiency in a bed planting system in northwest Mexico," Agronomy Journal, vol. 92, no. 2, pp. 303-308, 2000.

[14] SAS Institute, SAS/STAT Software Version 9.2, SAS Institute, Cary, NC, USA, 2008.

[15] A. M. Saxton, "A macro for converting mean separation output to letter groupings in Proc Mixed," in Proceedings of the 23rd SAS Users Group International, pp. 1243-1246, Nashville, Nashville, Tenn, USA, March 1998.

[16] R. Sylvester-Bradley and D. R. Kindred, "Analysing nitrogen responses of cereals to prioritize routes to the improvement of nitrogen use efficiency," Journal of Experimental Botany, vol. 60, no. 7, pp. 1939-1951, 2009.

[17] S. Muurinen, J. Kleemola, and P. Peltonen-Sainio, "Accumulation and translocation of nitrogen in spring cereal cultivars differing in nitrogen use efficiency," Agronomy Journal, vol. 99, no. 2, pp. 441-449, 2007.

[18] W. R. Raun and G. V. Johnson, "Improving nitrogen use efficiency for cereal production," Agronomy Journal, vol. 91, no. 3, pp. 357-363, 1999.

[19] K. G. Briggs, "Response of six-row barley to $\mathrm{N}$ and $\mathrm{P}_{2} \mathrm{O}_{5}$ fertilizer application in high fertility sites in central Alberta," Canadian Journal of Plant Science, vol. 71, no. 2, pp. 317-326, 1991.

[20] R. H. McKenzie, A. B. Middleton, L. Hall, J. DeMulder, and E. Bremer, "Fertilizer response of barley grain in south and 
central Alberta," Canadian Journal of Soil Science, vol. 84, no. 4, pp. 133-147, 2004.

[21] C. A. Grant, L. E. Gauer, and T. D. Gehl, "Yield response of semidwarf and conventional height barley cultivars to nitrogen fertilizer under varying moisture conditions," Canadian Journal of Plant Science, vol. 71, no. 2, pp. 361-371, 1991. 


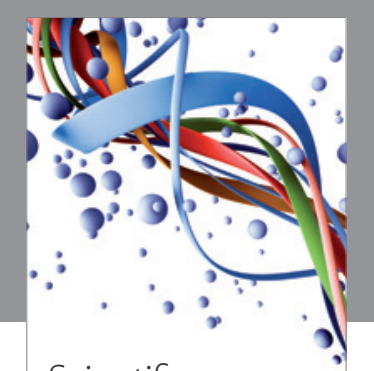

Scientifica
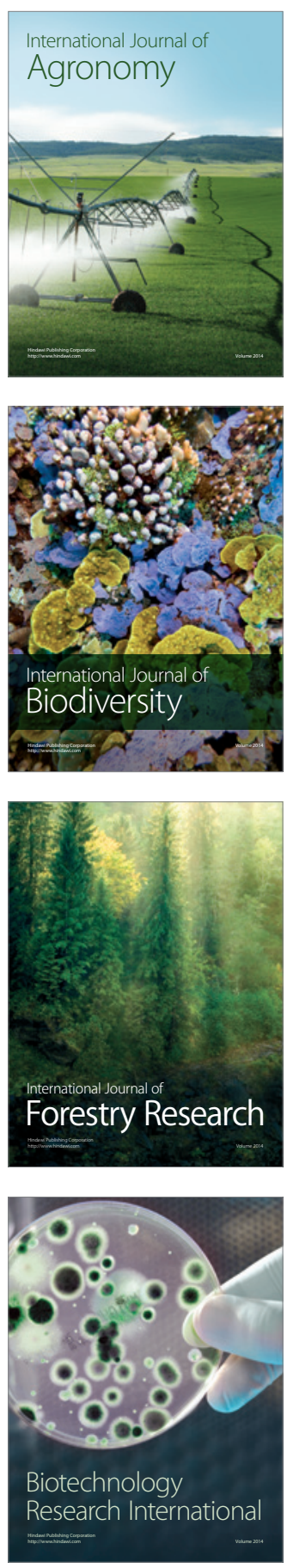
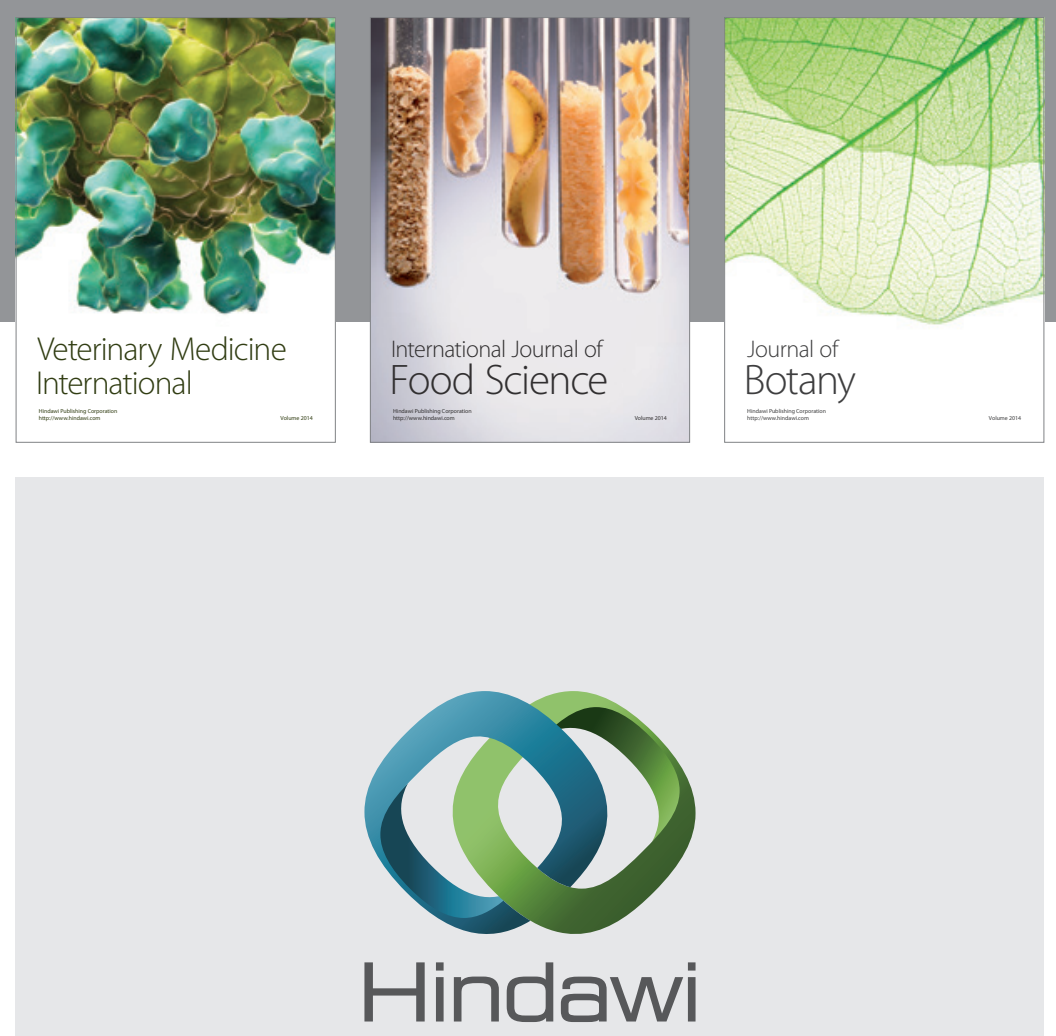

Submit your manuscripts at

http://www.hindawi.com
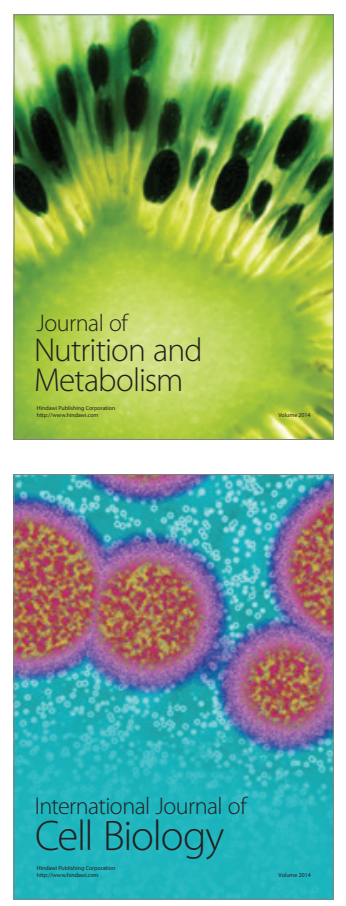
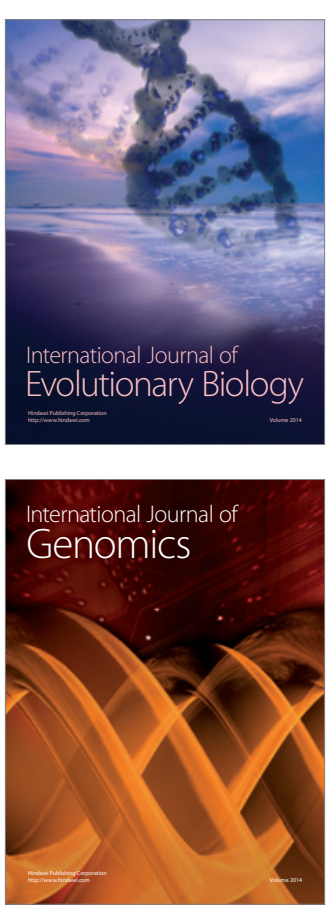
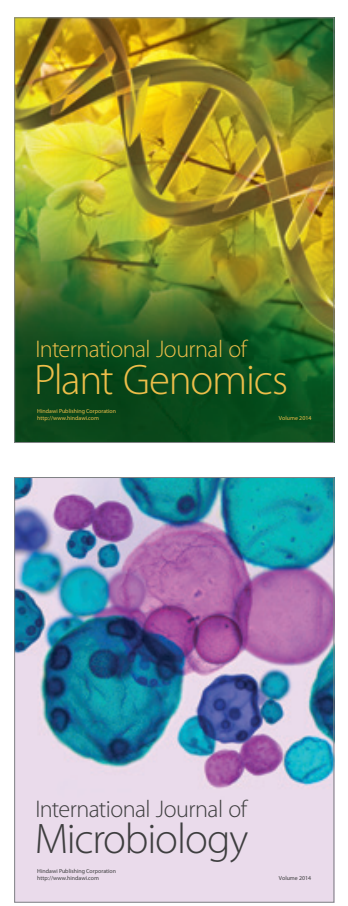

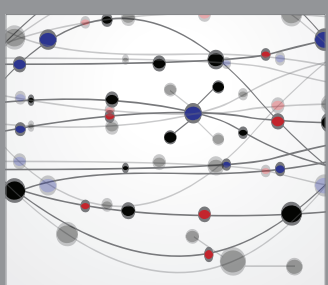

The Scientific World Journal
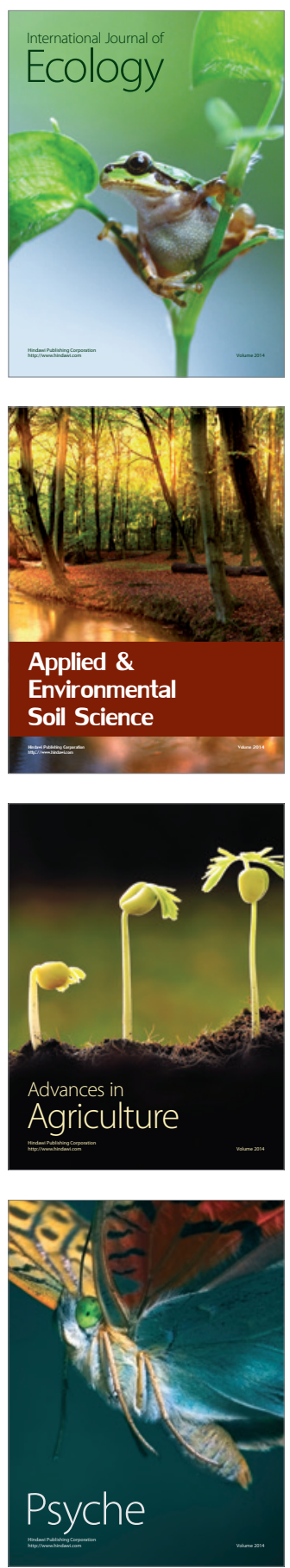